\title{
Kvėpavimo takų infekcijos gydymo strategija sergant cistine fibroze
}

\author{
Kęstutis Malakauskas \\ LSMU MA Pulmonologijos ir imunologijos klinika
}

Reikšminiai žodžiai: cistinė fibrozė, kvėpavimo takų infekcija, gydymas antibiotikais.

Santrauka. Straipsnyje trumpai aptariami pagrindiniai kvejpavimo takų patogenai sergant cistine fibroze, gydymas antibiotikais apimant infekcijos profilaktiką, ankstyvają infekcijos eradikaciją, lètinės infekcijos slopinimą ir infekcinių paūmëjimų gydymą.

\section{IVADAS}

Lètinès kvėpavimo takų infekcijos sukeliamas plaučių pažeidimas - viena svarbiausių cistine fibroze sergančių asmenų ligotumo ir mirštamumo priežasčių. Kad būtų išlaikyta stabili plaučių funkcija ir gera gyvenimo kokybė, sumažintas cistinès fibrozès infekcinių paūmèjimų dažnumas, reikalingi dažni ir intensyvūs gydymo antibiotikais kursai. Pseudomonas aeruginosa (P. aeruginosa) yra pagrindinis ir sunkiausius padarinius lemiantis bakterinis patogenas. Taigi šios infekcijos gydymo uždaviniai - ankstyva $P$. aeruginosa infekcijos eradikacija (pašalinimas) ir lètinès $P$. aeruginosa infekcijos slopinimas. Sèkmingas kvèpavimo taku infekcijos gydymas kartu su kitomis kompleksinèmis gydomosiomis priemonèmis lèmé tai, kad cistinès fibrozès ligonių gyvenimo trukmès mediana gerokai pailgèjo - nuo $14 \mathrm{~m}$. (1969 m.) iki $40 \mathrm{~m}$. (2010 m.).

Manoma, kad cistine fibroze sergantys asmenys gimsta turèdami neinfekuotus kvèpavimo takus, o oportunistinès patogeninès bakterijos ị apatinius kvėpavimo takus patenka iš aplinkos, dèl sutrikusio vietinio imuniteto juos kolonizuoja ir sukelia lètinị uždegimą. Dažniausiai pasitaikančios bakterijos yra $P$. aeruginosa, Staphylococcus aureus (S. aureus), Haemophilus influenzae, Stenotrophomonas maltophilia (S. maltophilia), Achromobacter xylosoxidans (A. xylosoxidans) ir Burkholderia cepacia. Lètinè infekcija sukelia ilgalaiki uždegimą, kuris sąlygoja plaučiu audinio pažeidimą ir destrukciją, pasireiškiančią plaučių funkcijos išnykimu.

Pagal bronchų sekreto pasèlio rezultatus kvėpavimo takų infekcija gali būti apibūdinama taip:

- Lètiné infekcija (angl. chronic infection) - dominantis patogenas išaugo daugiau nei 50 proc. bronchų sekreto pasèliu per pastaruosius 12 mèn.

- Epizodinè infekcija (angl. intermittent infection) - dominantis patogenas išaugo mažiau nei 50 proc. bronchų sekreto pasèlių per pastaruosius 12 mèn.

- Nera infekcijos (angl. free of infection) - per pastaruosius 12 mèn. dominantis patogenas nẻ karto neišaugo, nors anksčiau kvėpavimo takai buvo juo užsikrètę.

- Niekada nebuvo infekcijos (angl. never infected) - dominantis patogenas niekada nebuvo išskirtas.

\section{PSEUDOMONAS AERUGINOSA}

\section{$P$. aeruginosa eradikacija}

$P$. aeruginosa ị kvėpavimo takus dažniausiai yra įkvepiama ir gali laikinai infekuoti $10-50$ proc. visų sergančių cistine fibroze. Daliai ligonių patogenas iš kvejpavimo taku pasišalina savaime, t. y. bronchų sekreto pasèliai tampa neigiami, bet daugeliui $P$. aeruginosa infekcija/kolonizacija persistuoja. Irodyta, kad ankstyvos $P$ aeruginosa infekcijos/kolonizacijos intensyvus gydymas antibiotikais sergant cistine fibroze yra veiksmingas: patogenas 
dažnai išnaikinamas, kvėpavimo takai ilgiau išbūna neužsikrètę $P$. aeruginosa. Taigi, esant ankstyvai $P$. aeruginosa infekcijai ar kolonizacijai, rekomenduojama skirti eradikacini gydymą antibiotikais (1 pav.), bet iki šiol nèra tikslių gydymo rekomendacijų, kaip veiksmingai $P$. aeruginosa išnaikinti. Ivairių antipseudomoninių antibiotikų derinių ir vaistų formų (geriamųjų, inhaliuojamųjų, intraveninių) veiksmingumas yra panašus $-P$. aeruginosa eradikacija būna sèkminga vidutiniškai 80 proc. atvejų. $P$. aeruginosa eradikacijai antibiotikus ir jų vartojimo formas reikètų rinktis atsižvelgiant i galimą šalutini poveiki bei vaistų prieinamumą. Kaip $P$. aeruginosa eradikacijos strategiją galima rekomenduoti inhaliuojamojo tobramicino 28 d. kursą.

\section{Lètinès $P$. aeruginosa infekcijos gydymas}

Nors eradikacinis $P$. aeruginosa gydymas padejo sumažinti šios infekcijos dažnumą vaikams, suaugusiems pacientams $P$. aeruginosa tebèra vyraujantis patogenas (2 pav.). Lètinès $P$. aeruginosa infekcijos gydymui (slopinimui) vartojami inhaliuojamieji antibiotikai: aminoglikozido tobramicinas, polimiksino derivatas kolistinas, monobaktamas aztreonamas. Tyrimų rezultatai rodo, kad inhaliuojamieji antibiotikai yra saugūs ir jų klinikinè nauda pranoksta galimą riziką. Kitų inhaliuojamųjų antibiotikų (liposominio amikacino, ciprofloksacino, levofloksacino, fosfomicino/ tobramicino) klinikinis veiksmingumas dar tiriamas.

Lètinei $P$. aeruginosa infekcijai gydyti rekomenduojamas ilgalaikis inhaliuojamojo tobramicino vartojimas 4 savaičių kursais darant 4 savaičių pertraukas (jos daromos, kad būtų išvengta bakterijų atsparumo) arba nepertraukiamas kolistino vartojimas. Pacientams, kuriems kartojasi cistinès fibrozès paūmèjimai arba sparčiai blogejja plaučių funkcija, gali būti skiriamas pakaitinis (kas 4 sav.) gydymas dviem inhaliuojamaisiais antibiotikais, pvz., tobramicinu ir kolistinu.

\section{Lètinès $P$. aeruginosa infekcijos paūmèjimo gydymas}

Lètinei $P$. aeruginosa infekcijai paūmèjus, paprastai skiriamas kursas intraveniniu antipseudomoniniu antibiotikų, kad ligonis būtų apsaugotas nuo plaučių funkcijos pablogejjimo bei prailgintas laikas iki kito ligos paūmèjimo. Inhaliuojamųju antibiotikų klinikinis veiksmingumas gydant lètinès $P$. aeruginosa infekcijos paūmèjimą, nei vartojamų vienų, nei kartu su intraveniniais antibiotikais, nèra įrodytas. Tačiau inhaliuojamųjų antibiotikų, pvz., tobramicino, skyrimas gali būti svarstomas, kai sisteminio poveikio vaistai dèl šalutinio poveikio tampa nepriimtini, pvz., esant inkstų nepakankamumui. Gydymo antibiotikais kursas paprastai tęsiamas 10-14 dienų, jo trukmé labiau priklauso nuo klinikinès paūmejjimo eigos, o ne mikrobiologinių tyrimų rezultatų. Rekomenduojama gydymą tęsti iki išnyks paūmèjimo simptomai ir atsitaisys plaučių funkcija, bet neviršijant 3 savaičių (esant daugeliui vaistu atspariai $P$. aeruginosa, gydymo trukmė gali būti ir ilgesnè).

Pacientams, kuriems buvo nustatyta nauja $P$. aeruginosa infekcija ir taikytas eradikacinis gydymas, veiksmingumui ivertinti bronchų sekreto pasèlis atliktinas praejus 2-4 sav. po gydymo, toliau mikrobiologiniai tyrimai kartojami kas 3 mèn. Reguliariai daryti bronchų sekreto mikrobiologinius tyrimus tikslinga ir lètinę $P$. aeruginosa infekciją turintiems pacientams, ypač kuriems taikomas slopinamasis gydymas ar kartojantis ligos paūmèjimams. Reguliarūs serologiniai $P$. aeruginosa antikūnų tyrimai nerekomenduojami.

Antibiotiku jautrumą mikrobiologiniais tyrimais naudinga įvertinti ittariant $P$. aeruginosa daugini atsparumą vaistams, identifikavus naują $P$. aeruginosa padermę, dèl nepakankamo veiksmingumo keičiant gydymą antibiotikais. In vitro nustatytas patogeno atsparumas vartojamam antibiotikui nèra prielaida keisti antibiotiką, jei pasireiškia gydymo klinikinis efektas.

Profilaktinis cistine fibroze sergančių ligoniu gydymas antipseudomoniniais antibiotikais nepadeda ateityje išvengti $P$. aeruginosa infekcijos, todèl nèra rekomenduojamas.

\section{KITŲ BAKTERINIŲ PATOGENŲ INFEKCIJŲ GYDYMAS}

\section{Staphylococcus aureus}

S. aureus yra anksti ir dažnai nustatomas kvėpavimo takų patogenas, tikètina, susijęs su vèliau prisidedančia $P$. aeruginosa infekcija. Kai kuriose šalyse, pvz., Jungtinèje Karalysteje, rekomenduojamas profilaktinis $S$. aureus infekcijos gydymas. Tačiau, lyginant su profilaktiškai negydytais ligoniais, ilgametis profilaktinis gydymas antistafilokokiniais vaistais klinikiniu požiūriu nebuvo naudingas. Todèl jis, ypač suaugusiesiems, nerekomenduojamas.

Meticilinui atsparus $S$. aureus lemia sunkesnę cistinès fibrozès eigą, o jo paplitimas per pastaruosius dešimtmečius dideja. Meticilinui atspariu $S$. aureus užsikrètę pacientai dažniau hospitalizuojami, o dažniau užsikrečia turintieji F508del mutaciją, bronchektazių. Meticilinui atsparaus $S$. aureus infekcijos dažnumas sergant cistine fibroze yra panašus kaip visuomenèje. Todèl manoma, kad skirtingas šios bakterijos pasireiškimas įvairiose šalyse nepriklauso nuo skirtingu meticilinui atsparaus $S$. aureus gydymo strategijų.

\section{Stenotrophomonas maltophilia, Achromobacter xylosoxidans}

S. maltophilia infekcijos dažnumas, ịvairių cistinès fibrozès centrų duomenimis, yra skirtingas, o klinikinè infekcijos reikšmė lieka neaiški. Lètinè S. maltophilia infekcija susijusi su dažnesniais cistinès fibrozès paūmèjimais, bet neskatina sparčiau blogèti plaučiu funkcijos. Taigi paprastai gydoma lètinė $S$. maltophilia infekcija, pasireiškianti klinikiniu ligonio būklès blogèjimu.

Kol kas mažai žinoma apie A. xylosoxidans klinikinę reikšmę, todèl nèra rekomendacijų, kada ir kaip gydyti šią infekciją.

\section{Burkholderia cepacia komplekso padermès}

Burkholderia cepacia kompleksas - tai grupe septyniolikos artimai susijusių bakterinių padermių. Burkholderia 


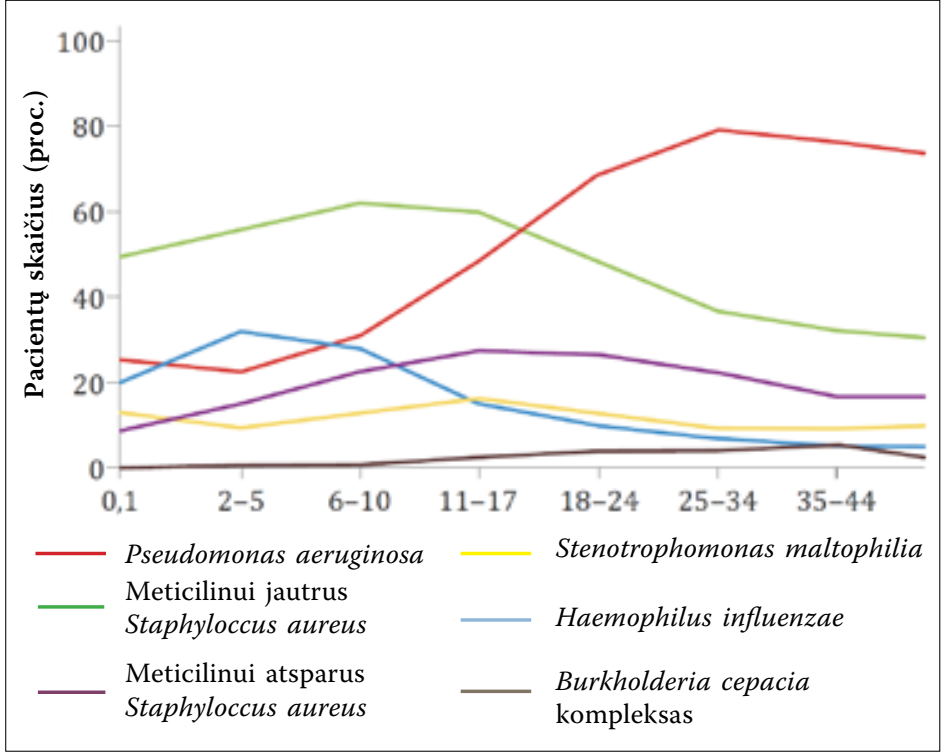

1 pav. Dažniausiai nustatomi kvèpavimo takų patogenai pagal cistine fibroze sergančių ligoniu amžiu

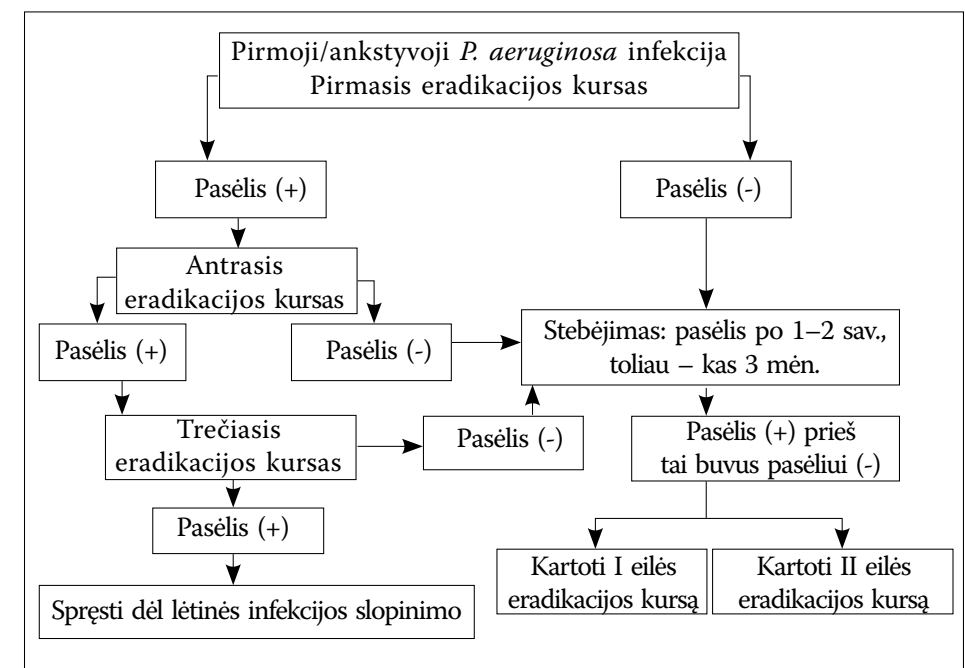

2 pav. Pseudomonas aeruginosa infekcijos eradikacinio gydymo antibiotikais algoritmas

\section{MANAGEMENT OF AIRWAY INFECTION IN CYSTIC FIBROSIS}

\section{KESTUTIS MALAKAUSKAS \\ LUHS MA DEPARTMENT OF PULMONOLOGY AND IMMUNOLOGY}

Keywords: cystic fibrosis, airway infection, antibiotic therapy.

Summary. In this review shortly are presented the major pathogens in cystic fibrosis, antibiotic therapy including prophylaxis against infection, eradication of early infection, suppression of chronic infection, and the treatment of infective exacerbations. cepacia komplekso infekcija būdinga sergant cistine fibroze, o dažniausios bakterijos yra B. cenocepacia, B. multivorans ir $B$. dolosa. Nors aiškių rekomendacijų nėra, tikslinga taikyti Burkholderia cepacia komplekso eradikacini gydymą, o lètinei infekcijai paūmejjus - gydymą kelių antibiotikų deriniu.

\section{Ne tuberkuliozès mikobakterijos}

$M$. aviumintracellulare kompleksas, $M$. chelonae ir M. abscessus kompleksas dažniausiai nustatomi vyresniems cistine fibroze sergantiems pacientams. Ne tuberkuliozès mikobakterijų infekcija sukelia spartų klinikinès ligos eigos blogejjimą. Todèl, kai cistinès fibrozès eiga blogèja, o kitų, kartu nustatytų, mikroorganizmų infekcijų antibakterinis gydymas neveiksmingas, reikia gydyti šią infekciją. Ne tuberkuliozès mikobakterijų infekcijos gydymas sudètingas: antibiotikais turi būti gydoma intensyviai ir ilgai. Tačiau kol kas visuotinai priimtos veiksmingos gydymo strategijos nèra.

Ilgalaikis makrolido azitromicino vartojimas, gydant lètinę $P$. aeruginosa infekciją, gali sąlygoti mikobakteriju atsparumą. Todèl azitromicinas neskirtinas esant ne tuberkuliozès mikobakterijų infekcijai (nors klinikiniuose tyrimuose neirodyta, kad makrolidai gali padidinti ne tuberkuliozès mikobakterijų infekcijos riziką).

\section{Anaerobiniai patogenai}

Anaerobinių bakterijų klinikinė reikšmė neaiški. Anaerobiniai patogenai būdingesni jaunesniems asmenims ir turintiems geresnę plaučių funkciją. Manoma, kad Prevotella intermedia gali sukelti kvèpavimo takų pažeidimą. Rekomendacijų, kada pradèti ir kaip gydyti anaerobinių patogenų infekciją, nèra.

\section{Aspergillus fumigatus}

Aspergillus fumigatus plitimas susijęs su inhaliuojamųjų antibiotikų vartojimu. Aspergillus fumigatus gali sukelti endobronchinę infekciją ar alerginę bronchopulmoninę aspergiliozę. Esant Aspergillus fumigatus infekcijai, skiriamas gydymas sisteminio poveikio vaistais nuo grybelių.

\section{LITERATŪRA}

1. Döring G, Flume P, Heijerman H, Elborn JS; Consensus Study Group. Treatment of lung infection in patients with cystic fibrosis: current and future strategies. J Cyst Fibros 2012; 11: 461-79.

2. Flume P, Mogayzel P, Robinson K., et al. Cystic Fibrosis Pulmonary Guidelines: Treatment of pulmonary exacerbations. Am J Respir Crit Care Med 2009; 180: 802-8.

3. Hauser AR, Jain M, Bar-Meir M, et al. Clinical significance of microbial infection and adaptation in cystic fibrosis. Clin Microbiol Rev 2011; 24: 29-70.

4. Mogayzel PJ, Naureckas ET, Robinson KA, et al. Cystic fibrosis pulmonary guidelines. Chronic medications for maintenance of lung health. Am J Respir Crit Care Med 2013; 187: 680-9.

5. Report of the UK Cystic Fibrosis Trust Antibiotic Working Group. Antibiotic treatment for cystic fibrosis. 3rd Edition, 2009.

6. Schelstraete P, Haerynck F, Van daele $S$, et al. Eradication therapy for Pseudomonas aeruginosa colonization episodes in cystic fibrosis patients not chronically colonized by P. aeruginosa. J Cyst Fibros 2013; 12: 1-8. 